\title{
Post-colonial Australia: Fact or fabrication?
}

\author{
Isabella Saunders
}

\begin{abstract}
This essay argues that Australia, while having made some substantive progress in the social and political reclamation of Indigenous rights, still maintains a powerful sense of colonisation. Examples surrounding the ideas of nationalism, land rights and recognition are drawn on to establish that Australia is undergoing the process of decolonisation, rather than having already done so.
\end{abstract}

Keywords: post-colonialism; Indigenous rights; nationalism; land rights; constitutional recognition

Post-colonialism describes the persisting cultural legacy within a nation that has experienced colonialism and imperialism. Ashcroft, Griffiths and Tiffin suggest that the term is used generally to define all cultures affected by the imperial process until the present time (1989, p. 2). Leading on from this, however, many theorists claim that it more accurately describes a nation that experienced colonialism, however the people themselves have been officially decolonised (Bunyan 2013). This is to say that there is no longer a sense of the 'coloniser' and the 'colonised'. According to Loomba et al., post-colonialism is also the "shifting and often interrelated forms of dominance and resistance" and "allows people emerging from socio-political and economic domination to reclaim their sovereignty; it gives them a negotiating space for equity" (2005, p. 2). Using this definition as a starting point, this essay will argue that Australia, while having made some substantive progress in the social and political reclamation of Indigenous rights, still maintains a powerful sense of colonisation. Examples surrounding the ideas of nationalism, land rights and recognition will be drawn on to establish that Australia is undergoing the process of decolonisation, rather than having done so already.

Post-colonialism suggests that colonialism has passed, and the group of people once subjugated to the control of imperialism have achieved sovereignty, self-determination and political recognition. Since the colonisation of Australia in the in the $18^{\text {th }}$ century, many developments have been made in regards to Indigenous justice, principally through their own engagement and determination within Australian society. The late 1960s were the formative years that shaped the basis of Indigenous 
activism and marked the beginning of social and political mobilization, as well as the emergence of Aboriginal nationalism (McGregor 2009, p. 343). The emergence of Indigenous cultural nationalism is one of particular importance, as it creates the space for empowerment and led the way for the reclamation of rights and liberties that had been denied up until that point. According to McGregor, "Aboriginal nationalism was an anti-colonial nationalism seeking a liberated future for the Aboriginal people along with an expansion of their rights and entitlements" (2009, p. 345).

It is clear here that the primary goal of Indigenous activists during this time was a post-colonial future, in which they were seen as equal citizens of the nation, and no longer the colonised, displaced and dominated people. New South Wales activists Jack Patten and Bill Ferguson proclaimed in their 1938 declaration "We ask - and we have every right to demand - that you [white Australians] should include us, fully and equally with yourselves, in the body of the Australian nation". The creation of a sense of nationalism amongst Indigenous people was a critical support in this goal, as national identities across the country could come together as one and fight for common rights and entitlements. The establishment of a common Aboriginal nationalism also created, as communicated by Ginsberg and Meyers, "great sympathy throughout Australia for recognition of indigenous rights to land, and created an Aboriginal culture and identity acceptable for national recognition" (2006, p. 33).

In using this sense of a common Aboriginal nationalism in regards to decolonisation, Aboriginal land rights are paramount. In a post-colonial nation, the previously oppressed peoples have succeeded in reclaiming sovereignty and their deserved entitlements concerning land rights and spatial autonomy (Loomba et al, 2005). During the $20^{\text {th }}$ century in Australia we have witnessed a great transformation in the privileges Indigenous Australians hold over their land, and in turn a reclamation of their sovereignty, independence and tradition. Particularly in the late 1970s, Indigenous activists were beginning to make substantial progress involving the reclamation of their land. With the designation of the Wran government, Aboriginal voices were heard for the first time and great political momentum was made (Norman 2015, p. 29), meaning that it was finally achievable to begin an inevitable yet gradual transformation toward decolonisation and an eventual post-colonial nation. This became even clearer during the 1978 Land Rights Inquiry, which sought to engage Indigenous people in ways they hadn't been previously (Norman 2015, p. 39). For the first time since colonisation, Indigenous people themselves were consulted in the decisions regarding their own future, with politicians appearing to make an active attempt to do things differently. In particular, throughout 1979 and 1980, the Inquiry committee met with locals across Australia, including rural Indigenous communities (Norman 2015, p. 39). As a result of this, Aboriginal activists and residents were able to convince the committee that land rights were central and incomparable in their goal in achieving justice and equal rights (Norman 2015, p. 43). In other words, decolonisation leading to a post-colonial nation would command a political system that entirely recognised the traditional landowners of Australia. While much progress has been made, particularly at the hands of Indigenous political and social activism regarding land rights, as well as the 1978 Land Rights Inquiry, this does not mean that Australia is, at present day, an entirely postcolonial nation.

The idea that Indigenous Australians can now actively partake in discussion and discourse regarding their welfare and future is in alignment with Webb's suggestion that "post-colonial is an enabling 
term, allowing previously silenced voices to be heard" (1992, p. 1) and a recognition of liberated differences. Following on from Webb's suggestion however, other questions must be asked, such as, "Who is defining and controlling the differences? Whose social and political needs are fulfilled by the claim that what was the 'colonial' is of the past?" $(1992$, p. 1). These questions raise the idea that through the immense transformation of the social and political landscape of Indigenous rights during the $20^{\text {th }}$ century, there still remains a powerful sense of colonisation in Australia. It is Webb's belief that it is not Aboriginal Australia that is in control of these differences, but rather the existing colonisers of the nation who continue to determine how Indigenous people are represented and which rights and justices they have access to (1992, p. 2).

This notion is similarly mirrored by Kathryn Trees, who asks, "Does post-colonial suggest colonialism has passed? For whom is it 'post'? Surely not for Australian Aboriginal people at least" (1993, p. 264). She goes on to explain that in the current Australian political landscape, Indigenous Australians continue to have a marked lack of access to land rights, social justice, respect and equal opportunity (Trees 1993, p. 264). While the development of Indigenous political activism, a growing sense of nationalism and the furthering of Land Rights and restoring of traditional ownership has made a distinct movement toward Aboriginal sovereignty and self-determination, there maintains a long path ahead to reach post-colonialism. Megan Griffiths recently summed this up, insisting "Australia has rejected self-determination - freedom, agency, choice, autonomy, dignity - as being fundamental to Indigenous humanness and development" (2016). Aboriginal sovereignty has, in many ways, not been legally recognised across Australia, including in the constitution. Furthermore, there remains several existing sections of the constitution that lend themselves to racial discrimination against Aborigines (Tudge 2015), and are holding the country back from a post-colonial status at a fundamental level.

Most crucial to this debate is the idea that until Indigenous sovereignty is legally recognised by the Australian government and the problematic sections are removed from the constitution, a powerful sense of colonialism is upheld and actively prevents the development of a post-colonial nation. In recent years, a crucial yet divisive discussion has surrounded this controversy, most notably in the form of the Recognise Campaign. The Recognise Campaign is a current political movement in Australia that is aiming to recognise Aboriginal and Torres Strait Islander peoples in the Australian Constitution. The goal of this campaign is to ensure that problematic sections of the Constitution are removed or edited to ensure it no longer lends itself to racial discrimination (Recognise 2016). According to Alan Tudge, the removal of the problematic sections in the constitution would force the parliament to make laws based on need, rather than indigeneity and would "reduce victimhood and focus on individual requirements" (2015). In other words, it would attempt to close the distance between the coloniser and the colonised, heading toward a more post-colonial future.

The Recognise Campaign follows the belief that this is the first step to achieving true equality and justice for Indigenous Australians. The basis of this follows the theory that until the founding document of Australia officially and legally recognises Indigenous Australians, and actively prevents their discrimination and marginalisation, it will be impossible to assert equality and begin a process of self-determination. Furthermore, it is clear that while certain sections of an official document actively lend themselves to the discrimination of a controlled and colonised group of people, we cannot label Australia as a country that has already undergone decolonisation. There are 
many ways in which Australia, as a colony, continues to treat the native and traditional landowners of this nation in a separate and destructive manner, maintaining a sense of ownership and otherness. However, the way in which the Recognise Campaign is being conducted also has many critics, and has become a controversial and problematic discussion in recent years. In analysing the comments in opposition to the campaign, it provides more insight into whether or not Australia is a postcolonial nation or rather has a long future ahead of measured decolonisation to realise this label.

Many Indigenous academics and campaigners are sceptical of a movement to have Aboriginal recognition in the founding document of the very same settler state that not only colonised the nation but has systematically oppressed Indigenous people for over 200 years. According to Celeste Liddle, the campaign appears in many ways to be a governmental tool that is well removed from grassroots Indigenous opinion (Liddle 2014). Without conferring with the views of Indigenous people, it appears as though these voices are again being silenced, which runs against Webb's theory of post-colonialism, in which previously silenced voices must be heard by the colonising state (Webb 1992). Instead, many Indigenous activists insist that the primary reason for the Recognise campaign is merely to comply with the standards set by the settler state. While it initially appears that constitutional and legal recognition is the next step forward, many are of the opinion that in remote Indigenous communities, there are greater issues to discuss and ones that are more currently relevant. In the words of Megan Davis, when the expert committee visited communities to discuss the campaign in 2014, "Despite being peppered with technical, legal questions about section this and subsection that, the witnesses spoke of the realities of life in their communities using the language of hopelessness, abandonment and despair" (2016). In this sense, it appears that many Indigenous community members are somewhat removed from the decisions and discussions surrounding these campaigns, amplifying the notion that they are a long way from selfdetermination and sovereignty.

The Recognise Campaign is set to go to referendum in 2017, with the Australian population voting on its success. Here, it would be assumed, the entirety of Australian citizens can have their voices heard, both Indigenous and non-Indigenous, thus implying that colonial power will no longer reside over the decision. However, the Australian Electoral Commission estimates only 58\% of Indigenous Australians are on the electoral roll, compared with 94\% of the overall population (Daley 2016). These enrolment rates are extremely unequal and point to larger systematic issues at hand within Australian society and the relationship colonial Australia has with Indigenous people. It also suggests that while it superficially appears that Aborigines are being included within issues related to their rights and futures, they are in many ways still methodically excluded and continue to be controlled by the predominantly white Australian government.

Overall, it may be said that while clear and beneficial progress has been made in the way of delivering Indigenous Australians with rights and justice, it would be inaccurate to describe Australia as a post-colonial nation. If the term post-colonial implies that the nation has undergone decolonisation, and the previously occupied group of people are no longer subjugated to control and limited agency, then Australia is realistically quite far from that objective. While the progressions made throughout Indigenous history have restored many rights to Aborigines, particularly in the way of land rights and social and political activism, the Indigenous voice is still lacking in many discussions nation-wide. The Recognise Campaign, while necessary in legally addressing the 
current constitutional issues, similarly excludes many opinions and continues to prioritise the speech of the colonising country, instead of attempting to bridge the gap with the traditional and native peoples of Australia.

\section{References}

Ashcroft, W., Griffiths, G., and Tiffin, H. 1989, The Empire Writes Back: Theory and Practice in Post-Colonial Literature, Routledge, London. https://doi.org/10.4324/9780203426081

Bunyan, M. 2003, 'Un/Settling Aboriginality', Art Blart, viewed May 27 2016, https://artblart.com/tag/australian-postcolonialism/.

Daley, P. 2016, 'There are lots of ways to say sorry, but Indigenous Australians need a treaty now', The Guardian, May 26, viewed May 28 2016, http://www.theguardian.com/australianews/postcolonial-blog/2016/may/26/there-are-lots-of-ways-to-say-sorry-but-indigenousaustralians-need-a-treaty-now.

Davis, M. 2016, 'Listening but not hearing', in Griffith Review: Fixing the System, Edition 51, Griffith University, Gold Coast.

Ginsberg, F., Myers, F. 2006, 'A History of Aboriginal Futures', in Critique of Anthropology, Vol. 26, Issue 1, Sage Publications, London, pp. 27 - 45.

Liddle, C. 2014, 'I don't want your Recognise campaign - It's nothing but a sham', The Guardian (Opinion), August 18, viewed May 30 2016, http://www.theguardian.com/commentisfree/2014/aug/18/i-dont-want-your-recognise-campaign-itsnothing-but-a-sham.

Loomba, A. et al. 2005, "Beyond What? An Introduction," in Loomba, Ania et al. (ed.,). Postcolonial Studies and Beyond. Durham, N.C.: Duke University, pp.1-38. https://doi.org/10.1215/9780822386650-001

McGregor, R. 2009, 'Another Nation: Aboriginal Activism in the Late 1960's and Early 1970's', Australian Historical Studies, vol. 40, no. 2, pp. 343 - 360.

https://doi.org/10.1080/10314610903105217

Norman, H. 2015, 'Government, Aborigines and Power: the NSW Land Rights Inquiry', Chapter 2 in 'What Do We Want? A Political History of Land Rights, Aboriginal Studies Press, Canberra, pp. $29-49$.

Patten, J. T., Ferguson, W. 1938, 'Aborigines Claim Citizen Rights! A statement of the case for the Aborigines Progressive Association’, Sydney, Publicist, 1938.

Trees, K. 1993 “Postcolonialism: Yet Another Colonial Strategy?” in Span, Vol. 1, No. 36, 1993, pp. 264-265.

Tudge, A. 2015, 'The case for Indigenous constitutional recognition', The Australian (Opinion), June 11, viewed May 30 2016, http://www.theaustralian.com.au/opinion/the-case-for-indigenousconstitutional-recognition/news-story/4a2c8657cbcf906b09834ad789d23629. 
NEW: Emerging scholars in Australian Indigenous Studies 2017-18

Webb, H. 1992, 'Doin' the post-colonial story? Neidje, Narogin and the Aboriginal narrative intervention', Journal of the South Pacific Assoc for Cwlth Lit and Language Studies, Number 32.

(C) 2018 by the author. This article is distributed under the terms and conditions of the Creative Commons Attribution license (http://creativecommons.org/licenses/by-nd/4.0/). 